\title{
Analysis of Information Technology Application in The Quotation Unit PT Asuransi Sinar Mas Using Cobit 5 Framework
}

\author{
Richad Agustinus Kusuma D \\ Information System, Kristen Satya \\ Wacana University, Salatiga, \\ 50715, Indonesia \\ 682016059@student.uksw.edu
}

\author{
Yani Rahardja \\ Information System, Kristen Satya \\ Wacana University, Salatiga, \\ 50715, Indonesia \\ yani.rahardja@uksw.edu
}

\author{
Melkior N. N. Sitokdana \\ Information System, Kristen Satya \\ Wacana University, Salatiga, \\ 50715, Indonesia \\ melkior.sitokdana@uksw.edu
}

\begin{abstract}
The application of information technology in an organization can add value to effectiveness and efficiency in achieving organizational goals, therefore it is necessary to assess the management of information technology in the organization. Analysis of the application of information technology in this research using the COBIT 5 framework which focuses on the subdomains BAI04, BAI09, and MEA01. Assessment of the application of information technology in the Quotation Unit division at PT. Asuransi Sinar Mas, which already using information technology in every business process carried out in the division. The overall result of the application of technology in the Quotation Unit division reaches level 3 (Defined Level). From the results obtained, recommendations were made for the Quotation Unit division to reach the level desired by PT. Sinar Mas Insurance is level 4 (Managed) so that it can support the organization in achieving the goals in terms of information technology.
\end{abstract}

Keywords- COBIT 5, Technology Application, Capability Level.

\section{INTRODUCTION}

The role of technology at the time is very influential for organizations because it can get added value, namely, the value of effectiveness and efficiency in business processes besides that information technology is an investment for the company. Therefore, organizations must maximize information technology in order to support business processes to achieve organizational goals. Maximization of information technology can be seen from various aspects such as hardware, software, brainware and networks.

Conducting analysis on the application of information technology is one way to maximize the use of information technology in an organization using several frameworks such as COBIT, COSO, ITIL, and ISO. For this reason, this research using the COBIT 5 (Control Objectives for Information and Related Technology) framework which is an update of COBIT 4.1.
An assessment of this framework will give a value on how big the role of information technology in an organization.

The COBIT framework consists of an executive summary, framework, control objectives, audit guidelines, implementation toolset, and management guidelines which are very useful for strategic information system processes. COBIT is useful for users to gain confidence in the application of information technology. while COBIT managers are used to making decisions when compiling strategic IT plans, determining procurement or purchasing organizational inventory. COBIT 5 provides a more complete framework than COBIT 4.1, namely the existence of 5 domains and 37 processes in COBIT 5 which are deemed appropriate and can assist in the audit process and evaluation of the application of information technology because in COBIT 5 there are all the elements needed.

PT. Sinar Mas Insurance is part of Sinar Mas which was established on May 27, 1985, under the name PT. Asuransi Kerugian Sinar Mas Dipta and in 1991 changed its name to PT. Asuransi Sinar Mas "ASM". As a General Insurance Company, PT. ASM proves its commitment to customer service through fast and accurate claim payments for the various products it markets. Besides that, PT. ASM also makes it easy for customers, partners, and partners/agents to access all matters related to insurance through the website, 24 Hour Customer Care Call Center (Sinarmas, n.d.-a).

On the product side, ASM has many products to protect assets, the health of customers and companies, besides that there is also Marine / Transportation, Engineering / Engineering, Insurance, Accident and Health insurance, Motor Vehicles, Liability, and Miscellaneous. In motorcycle vehicle insurance products, there is a Procurement division with a Quotation Unit sub-division that is tasked with validating the procurement of spare parts for the replacement of customer-owned motorcycle vehicle spare parts, which invalidating uses an e-part system that is connected to suppliers who supply spare parts for the needs of PT. ASM uses the tokoonderdiil.id website. However, in the use of the system, there are problems such as system 
errors both from the admin and supplier sides in validating spare parts. In addition, there are hardware and networks that do not meet the needs of running the business processes at PT. ASM.

Based on the problem, the authors chose to use COBIT to provide suggestions and recommendations for the right application of IT so that it can be used as a guide that can be used and can support business processes within the company so that it can run optimally.

Evaluation of IT Governance using COBIT 5.0 in the Company has been carried out by various previous researchers, therefore in this research, some relevant research will be taken to serve as a reference for writing this research.

Framework PT Santani Agro Persada, in this study the average value of the MEA03 process was obtained with a value of 3.653 which is included in the maturity scale at level 4 (managed and measurable), which means evaluation, and research on compliance with External requirements are good even though there is still a gap from what was expected at PT Santani (Syaputra, 2018).

Further related research is the audit of information technology governance using the Cobit 5 framework (Case Study: Lampung Marine Cultivation Fisheries Center) conducted by Ryan Randy Suryono and friends, in this research the average value for the domains MEA, APO, BAI was obtained. , DSS and MEA are 2.8 from a value range of 0 to 5 which means that the Lampung Marine Cultivation Center for Fisheries has carried out a security process that has followed the existing standards but with the average value obtained there is a fatal weakness, namely not having a standard procedure in the process of securing data and information (Suryono, Darwis, \& Gunawan, 2018).

Research on the Evaluation of Information Technology Governance using the COBIT 5 framework conducted by Septi Fajarwati and friends from STMIK Amikom Purwokerto in 2018, obtained results in the process of the EDM01, EDM02, EDM03, EDM05 domains, the level of IT implementation in the Baturraden District Office was obtained. at level 1 on a scale of 0 to 5 with a value of 1.75. This shows that IT at the Baturraden District office has been running and achieving its goals but there has been no process to ensure the benefits in the delivery process and risk optimization have been determined, and outputs are as expected (Fajarwati \& Septiana, 2018).

In the research of Information Technology Governance Evaluation at PT. Aerofood Indonesia Soekarno Hatta Airport Cengkareng Using COBIT 5.0 Framework. In this research, there were obstacles to IT implementation due to the absence of complete documentation and the absence of a chart or interface window to communicate IT problems effectively (Soejanto \& Perdanakusuma, 2018).

\section{LITERATURE REVIEW}

In this research the problems include:

A. PT. Asuransi Sinar Mas has implemented IT but, in its use, it has not yet reached the maximum stage.
Therefore, it is necessary to analyze the application of IT so that it can be maximized and help achieve organizational goals.

B. The limitation of this research only refers to the application of information technology at PT. Asuransi Sinar Mas.

C. The end result of this determination resulted in a recommendation for PT. Asuransi Sinar Mas.

\section{RESEARCH METHODS}

The following describes the research object, methods and stages of the research conducted;

\section{A. Information Technology}

According to Bambang Warsita (2008), information technology is facilities and infrastructure (hardware, software, user) systems and methods for obtaining, sending, processing, interpreting, storing, organizing, and using data meaningfully. The same thing was also expressed by Lantip and Rianto (2011) that information technology is defined as knowledge in the field of computer-based information and its development is very rapid. Hamzah B. Uno and Nina Lamatenggo (2011) also suggest that information technology is a technology used to process data. The role of information technology is very important because it is one of the factors to achieve organizational goals. The role of technology will be optimal if the application of information technology is well managed. Good management of information technology can be assessed from the alignment of IT application with organizational needs that comes from needs according to Richardus Eko (2016). There are three things to manage IT implementation well, namely human resources, technology, and relationships.

The existence of human resources is very influential because human resources are responsible for the operation of all technology used in the organization and can also solve problems that exist within the organization. While technology includes all infrastructure related to technology, both hardware, and software used in the organization to support existing business processes. Technology and Human Resources have an important relationship because in the application of information technology it can help decision making by using a framework so that every decision taken can develop the use of IT in the organization (Institute, 2007).

\section{B. COBIT 5}

Control Objective for Information \& Related Technology (COBIT) is a collection of best practice documentation for IT Governance that can help auditors, users, and management, to bridge the gap between business risks, control needs, and IT technical problems (Sasongko, 2009).

COBIT supports IT governance by providing a framework for managing IT alignment with the business. In addition, the framework also ensures that IT enables business, maximizes profits, IT risks are managed appropriately, and IT resources are used responsibly 
(Tanuwijaya and Sarno, 2010). additional domains from 4 domains in 4.1, namely planning and organization (PO), Acquisition and Implementation (AI), Delivery and Support (DS) and Monitoring (M) into 5 domains namely EDM, APO, BAI, DSS, and MEA (ISACA, 2012), and there is a change in the principle of grading maturity, in COBIT 4.1 the organization is only required to meet at least one requirement in one quadrant to proceed to the next quadrant, while in COBIT 5 the organization must meet all the requirements to proceed to the next quadrant.

According to ISACA in the Evaluate, Direct, and Monitor (EDM) domain, it includes governance that ensures that organizational goals have been met by evaluating the needs of stakeholders, conditions, options in decision making using a priority scale, and monitoring performance, compliance, and progress towards objectives were agreed.

While the domain Align, Plan, and Organize (APO) includes the use of information technology appropriately to achieve company goals and objectives. This domain also highlights the form of organization and infrastructure that must be taken to achieve the greatest impact of a company's information technology.

In the Build domain, Acquire and Implement (BAI) includes identification of requirements (IT), acquiring technology until its application in company business processes.

Then the domain Deliver, Service, and Support (DSS) focuses on aspects of the way information technology is delivered including its execution in the system and the result is also a support process that allows effective and efficient execution of IT systems in the organization.

Domain Monitor, Evaluate and Assess (MEA) is related to the company's strategy in assessing the company's needs and evaluating the information technology used today that still meets the objectives that are designed and controlled to meet the requirements set by the company. Meanwhile, monitoring includes the problem of assessing the effectiveness of information technology systems in meeting organizational goals (ISACA, 2012a).

\section{Research Stages}

As the object of research, the author conducted a review at PT Asuransi Sinar mas Head Office, which is located at Fachrudin street No. 18, Tanah Abang, Central Jakarta, DKI. Jakarta. In this study, the authors used primary data using quantitative data which, according to Sugioyono, the method used to study a particular population or sample, data collection using quantitative data analysis, by conducting surveys and data collection by distributing questionnaires while for secondary data obtained from previous journals which aim to determine the maturity level of the application of information technology by using the COBIT 5 framework as a tool to analyze problems that occur and provide recommendations regarding the application of information technology.
Stage 1. The author conducted a literature study by collecting literature and information related to the research title. The author is also looking for information that can help research through several references. Reference materials are taken from books, the internet, scientific papers, dissertations, journals, theses, papers, and thesis.

Stage 2. The author identifies what problems will be discussed regarding the application of information technology in the company based on the literature and information that has been obtained.

Stage 3. To determine what kind of data is needed based on population, sample, and sampling method. Then determine the research subject and respondent.

Stage 4. Primary data collection, the author distributes questionnaires to samples that use information technology, while to obtain secondary data the authors read previous documents such as journals discussing the same research conducted in other companies.

Stage 5. After obtaining the data, the author analyzes the data obtained which will then be processed using the COBIT 5 framework to obtain a capability level where this measurement model is based on ISO / IEC 15504 Software Engineering-Process Assessment Standard. There are 6 levels that must be achieved in each process (ISACA, 2012) and then a Gap analysis is obtained.

Stage 6. Writing criticism and recommendations to the company for further research.

\section{RESULTS AND DISCUSSION}

\section{A. COBIT 5 Domain Identification Process}

In measuring the maturity level of technology adoption at PT. Asuransi Sinar Mas based on distributing questionnaires to the Quotation Unit section, the IT Team that manages the Quotation Unit section. The first step is to determine the business objectives of PT. Sinar Mas Insurance is based on the Vision and Mission and will further state the IT goals of PT. Asuransi Sinar Mas in accordance with COBIT 5 uses the Balance Scorecard Dimension (BSC). The existing vision at PT. Asuransi Sinar Mas is: "To be a professional and trusted insurance company by providing meaningful value to our customers, reinsurance companies, agents, partners, shareholders, and employees." To realize this vision, a mission was formed as follows:

a) Know and meet customer needs

b) Favorable underwriting results

c) Develop talents, increase employee productivity and efficiency

d) Sustainable product innovation and development of information technology (Sinarmas, n.d.-b)

From the vision and mission points above, the last point of the mission is taken, namely product innovation and continuous development of information technology because it is in accordance with the IT goals that PT. Asuransi Sinar Mas. The mapping process is carried out using the Enterprise Goals and IT-Related Goals tables. 
The first step is matching the goals of PT. Asuransi Sinar Mas with Enterprise goals as in table 1.

Table 1. Mapping of PT. ASM into Enterprise Goals

\begin{tabular}{|l|l|l|l|l|}
\hline $\begin{array}{l}\text { Business } \\
\text { Goals }\end{array}$ & No & $\begin{array}{l}\text { Objectives } \\
\text { Enterprise }\end{array}$ & $\begin{array}{l}\text { BSC } \\
\text { Dimension }\end{array}$ & Relationship \\
\hline $\begin{array}{l}\text { Continuous } \\
\text { product } \\
\text { innovation } \\
\text { and } \\
\text { development } \\
\text { of information } \\
\text { technology }\end{array}$ & 1 & $\begin{array}{c}\text { Stakeholder } \\
\text { value of } \\
\text { bussiness } \\
\text { investment }\end{array}$ & Financial & Primary \\
\cline { 2 - 5 } & 7 & $\begin{array}{c}\text { Bussiness } \\
\text { service } \\
\text { continuity } \\
\text { and } \\
\text { availbillity }\end{array}$ & Customer & Primary \\
& & & \\
\hline
\end{tabular}

After mapping the business objectives into Enterprise Goals, where there are two enterprise goals, namely the Stakeholder value of a business investment and Business service continuity and availability, then IT objectives to be achieved can be determined as in Table 2 .

Table 2. Mapping of Enterprise Goals into IT-Goals

\begin{tabular}{|c|l|c|l|l|}
\hline $\begin{array}{c}\text { Enterprise } \\
\text { Goals }\end{array}$ & No & IT Goals & $\begin{array}{l}\text { BSC } \\
\text { Dimension }\end{array}$ & Relationship \\
\hline $\begin{array}{c}\text { Stakeholder } \\
\text { value of } \\
\text { bussiness } \\
\text { investment }\end{array}$ & 11 & $\begin{array}{c}\text { Optimisa } \\
\text { tion of IT } \\
\text { Asset, } \\
\text { Resource } \\
\text { s and } \\
\text { Capabilit } \\
\text { es }\end{array}$ & Internal & Primary \\
\hline $\begin{array}{c}\text { Bussiness } \\
\text { service } \\
\text { continuity } \\
\text { and } \\
\text { availbillity }\end{array}$ & 7 & $\begin{array}{c}\text { Manage } \\
\text { IT- } \\
\text { Related } \\
\text { bussiness } \\
\text { risk }\end{array}$ & Financial & Primary \\
\hline
\end{tabular}

After mapping from enterprise goals to IT goals, one IT destination is taken at each enterprise destination which will later be used to determine the domain to be taken as the basis for assessing IT implementation that has been carried out in the Quotation Unit at PT. Asuransi Sinar Mas and the domain that will be used in the assessment will be mapped from the IT objectives as shown in table 3 .
Table 3. Mapping IT-Goals into Domain and Subdomain

\begin{tabular}{|c|c|c|c|}
\hline IT Goals & Domain & $\begin{array}{c}\text { Sub } \\
\text { Domain }\end{array}$ & Avtivity \\
\hline \multirow[t]{2}{*}{$\begin{array}{l}\text { Optimisation of } \\
\text { IT Asset, } \\
\text { Resources and } \\
\text { Capabilites }\end{array}$} & BAI & BAI04 & $\begin{array}{ll}\text { - } & \text { Managing } \\
\text { Human } & \\
\text { Resources } & \\
\text { - } & \text { Assess how } \\
\text { much } & \text { IT } \\
\text { influences } & \end{array}$ \\
\hline & & BAI09 & $\begin{array}{ll}\text { - Manage } & \text { IT } \\
\text { assets }\end{array}$ \\
\hline $\begin{array}{c}\text { Bussiness } \\
\text { service } \\
\text { continuity and } \\
\text { availbillity }\end{array}$ & MEA & MEA01 & $\begin{array}{lr}\text { - Analyze } & \text { and } \\
\text { report } & \text { on } \\
\text { performance } & \end{array}$ \\
\hline
\end{tabular}

\section{B. RACI Chart}

In obtaining the necessary information by distributing questionnaires to employees, the IT team and department heads in this research based on the RACI Chart mapping. In the mapping, the RACI Chart differs according to the subdomain or activity in order to provide an evaluation of each activity. The division of RACI is divided as follows: $\mathrm{R}$ is the party or part that runs the process, $\mathrm{A}$ is the party or part that is responsible for the process, $\mathrm{C}$ is the party who provides input to the existing process, I is the party who gets the information. This research on the RACI Chart is based on the responsibility for the process (ISACA, 2012) in managing or using the Information Technology in the Quotation Unit section as in table 4.

Table 4. RACI Table

\begin{tabular}{|l|c|c|c|c|}
\hline \multicolumn{1}{|c|}{ Information } & R & A & C & I \\
\hline Head of Department & & & $\mathrm{v}$ & \\
\hline Coordinator & $\mathrm{v}$ & & & \\
\hline IT Team & & $\mathrm{v}$ & & \\
\hline User & & & & $\mathrm{v}$ \\
\hline
\end{tabular}

C. Capability Level Analysis

Capability level is done to determine the process of implementing information technology in the Quotation Unit at PT. Asuransi Sinar Mas. In measuring the level of maturity, questionnaires were distributed to employees of the Quotation Unit, Head of Department and the PIC of the IT team who were responsible for the e-claims and PEGA applications used in the Quotation Unit section using the calculation (1)

$$
\begin{aligned}
& \text { Attribute Capability Index }=\frac{z(\text { Total Answers } x \text { weight })}{\text { Number of Respondents }} \\
& \text { Capability Index }=\frac{\text { EAttribute Capability Index }}{\text { Activity }}
\end{aligned}
$$

\section{Calculation of Capabilities and Gaps}

After identifying business processes and distributing questionnaires to employees in the quotation department, the following results were obtained. 
Table 5. Measuring Result Maturity Level

\begin{tabular}{|l|l|l|l|}
\hline \multicolumn{1}{|c|}{ Activity } & \multicolumn{1}{|c|}{$\begin{array}{c}\text { Current } \\
\text { Conditions }\end{array}$} & \multicolumn{1}{|c|}{ Expected } & Gap \\
\hline BAI 04 & 4,00 & 4,00 & - \\
\hline BAI 09 & 3,46 & 4,00 & 0,54 \\
\hline MEA 01 & 3,69 & 4,00 & 0,31 \\
\hline
\end{tabular}

Based on the results of measuring the level of maturity in the Quotation Unit section, the findings of the application of information technology in the quotation unit section at PT. Asuransi Sinar Mas as follows:

1. BAI04 (Manage Availability and Capacity)

This domain has reached level 3 (Defined Level) because at PT. Asuransi Sinar Mas, especially the Quotation Unit section for software used such as PEGA, E-Claim and Microsoft Office, has been able to help achieve goals and there are still frequent errors, but for each error, documentation has been carried out and then given to the IT team to be corrected and in the use of software, licensed software such as PEGA is used to determine the winner of the tender, while the existing hardware is quite helpful in achieving the company's goals even with standard specifications that cause errors occur when software updates.

2. BAI09 (Manage Asset)

In this domain, it has reached level 4 (Managed) because at PT. Asuransi Sinar Mas has implemented asset management such as existing human resources for IT operations, especially software such as PEGA, E-Claim, and Microsoft Office. that human resources and information technology are a unit that can assist in achieving the goals of an organization and the results are in line with expectations.

3. MEA01 (Manage Performance and Conformance Monitoring)

This domain has reached level 3 (Defined Level) because at PT. Asuransi Sinar Mas, especially the Quotation Unit section, has monitored employee performance by sending work reports that have been given in the morning to the coordinator every day and are given the responsibility to employees for the IT assets used and if there is damage to the IT assets used, the employee is obliged to report it as documentation and the IT assets are taken and repaired first without any replacement if the damage is minor.

\section{E. Recommendation}

After calculating the capabilities and gaps, the author provides advice on domains that have not reached expectations for PT. Asuransi Sinar Mas as follows:

1. BAI04 (Manage Availability and Capacity)

The advice given is routine maintenance so that the existing software continues to run so that it does not hamper the work and rejuvenation of the hardware used, especially the computer used because along with the software update, adequate hardware specifications are needed.
2. MEA01 (Manage Performance and Conformance Monitoring)

The advice given, especially in safeguarding IT assets, is that reporting on assets should be carried out routinely, such as once a month so that you can find out which assets need to be replaced with existing reserve assets if the condition of the assets is abnormal so that work is not disturbed.

\section{CONCLUSION}

Based on the results of the data analysis, it is seen that the application of information technology in the quotation unit of PT. Asuransi Sinar Mas is at an average level of 3.72 with the translation on the domain BAI04 getting the level of 3.46, the BAI09 domain getting the level of 4.00, and in MEA01 getting the level of 3.69. At this maturity level, almost the entire application of information technology in the quotation unit of PT. Asuransi Sinar Mas is well managed in terms of both implementation and budgeting.

The suggestions from the author for further research require a special assessment of the PEGA 8 system which is currently under development because in the future all applications used will use PEGA 8.

\section{REFERENCES}

Fajarwati, S., \& Septiana, Y. (2018). Evaluasi Tata Kelola Teknologi Informasi Menggunakan Kerangka Kerja COBIT 5 (Evaluation of Information Technology Governance Using COBIT 5 Framework). VI(November), 73-80.

Institute, I. G. (2007). COBIT 4.1 : Framework Control Objectives Management Guidelines Maturity Models.

ISACA. (2012a). COBIT 5 : A Business Framework for the Governance and Management of Enterprise IT.

ISACA. (2012b). COBIT 5 : Enabling Processes.

ISACA. (2012c). COBIT 5 : Main Framework Version 2.

Sinarmas. (n.d.-a). Sejarah ASM. Retrieved from www.sinarmas.co.id/tentang-kami/sejarah-asm

Sinarmas. (n.d.-b). Visi dan Misi. Retrieved from https://www.sinarmas.co.id/tentang-kami/visi-danmisi

Soejanto, J., \& Perdanakusuma, A. R. (2018). Evaluasi Tata Kelola Teknologi Informasi pada PT . Aerofood Indonesia Bandar Udara Soekarno Hatta Cengkareng dengan Menggunakan. 2(11), 4714-4721.

Suryono, R. R., Darwis, D., \& Gunawan, S. I. (2018). Audit Tata Kelola Teknologi Informasi Menggunakan Framework Cobit 5 (Studi Kasus: Balai Besar Perikanan Budidaya Laut Lampung). 12(1), 16-22.

Syaputra, S. D. (2018). Jurnal Tata Kelola Teknologi Informasi Menggunakan Framework Cobit 5 PT. Santani Agro. 